\title{
Assessing Problems and Prospects of Solid Waste Management in Malaysia
}

\author{
Innocent A. Jereme \\ Institute for Environment and Development (LESTARI) \\ National University of Malaysia (UKM), Malaysia \\ E-mail: innoviva2001@yahoo.com \\ Rawshan Ara Begum \\ Institute of Climate Change (IPI) \\ National University of Malaysia (UKM), Malaysia \\ Basri Abdul Talib \\ Faculty of Economics and Management \\ National University of Malaysia (UKM), Malaysia \\ Chamhuri Siwar \\ Emeritus Professor \\ Institute for Environment and Development (LESTARI) \\ National University of Malaysia (UKM), Malaysia \\ E-mail: csiwar@ukm.my \\ Md. MahmudulAlam \\ PhD Student, Institute for Environment and Development (LESTARI) \\ National University of Malaysia (UKM), Malaysia \\ E-mail: rony000@gmail.com
}

\section{Citation Reference:}

Jereme, I.A., Siwar, C., Begum, R.A., Talib, B.A., and Alam, M.M. 2015. Assessing Problems and Prospects of Solid Waste Management in Malaysia, e-Bangi, Vol. 10(2), pp. 70-87. [ Online Link ]

This is a pre-publication DRAFT copy.

The published article is copyrighted by the publisher of the journal. 


\begin{abstract}
Malaysia has seen a high rate of economic growth in past couple of decades hand in hand with an ever increasing size of population. As a consequence, the issue of sustainable waste management has become an important priority for policymakers and other stakeholders of the society. Although there are potentials to recycle up to 80 per cent of the total dry wastes collected, currently most of them are deposited into various landfill sites. Waste treatment facilities are also insufficient in the country. The government has introduced SWM Act 2007 along with other initiatives to improve the waste management scenario, but more needs to be done to be able to recycle and treat a major portion of the wastes. Based on studies on the state of Selangor in Malaysia, this paper this paper attempts to analyse the waste management scenario of Malaysia and the problems and prospects of waste recycling there. The paper will help the policy makers, waste management strategists, local administrators and researchers in the field to formulate sustainable policies and identify further areas of study in the relevant field.
\end{abstract}

Keywords: Recycling, landfills, waste management, solid waste, environment, Malaysia

\title{
1. INTRODUCTION
}

Waste management refers to the collection, transportation, processing, recycling or disposal of waste materials, usually one produced by human activities in an effort to reduce their effects on human health and aesthetics or amenities. Waste management is a polite term for garbage management. As long as humans have been living in settled communities, solid waste or garbage has been an issue of concern. Modernisation generates far more solid wastes than early humans ever did. Daily life generates several pounds of solid waste per consumer, not only directly in the home, but indirectly in factories that manufacture goods purchased by consumers.

The issue of waste disposal management has recently gained widespread attention in virtually all states of Malaysia. With the communities facing rapidly increasing disposal costs, the opinion leaders denouncing the amount of materials being thrown away as environmentally and ethically unsound, the lawmakers struggling for sustainable solutions pressure is mounting on manufactures and packagers of consumer goods to minimise the amount of refuse. Amidst these changing circumstances, some laws have recently been passed making waste management a national issue in Malaysia and many others have similar laws on their agenda (Yahaya 2007a).

Hand in hand with the high rate of economic growth in the past few decades, the population of Malaysia have grown from 21,793293 in 2000 to 28,339273 in 2010/11. Considering these economic and population growths together, Malaysia is generating more wastes now in comparison to any previous point of time in history. It is estimated that about 18,000 tons of wastes are generated in Malaysia per day and this figure is expected to increase at the rate of $2 \%$ every year. Out of these, $75 \%$ of the wastes generated are collected and disposed at dumpsites or landfills that are not sanitary. In Kuala Lumpur, only 5\% of the wastes generated in the city are recycled and the rest goes to landfills (Yassin 2006). 
As of April 2007, there were 291 landfill sites in Malaysia to dump wastes, out of which only ten were sanitary landfills; of these 291 sites, 112 were closed and the remaining 179 were still in operation. It is expected that solid waste generation in Malaysia will reach 30,000 tons per day in 2020 (Yahaya 2007a). A waste reduction study conducted by the Local Government Authority indicates that food waste and other organic waste constitute $47 \%$ of the total wastes generated, followed by paper $15 \%$, plastics $14 \%$, and others constitute the rest (Yassin 2006). In 2020, there is target to recycle 20\% of the total wastes generated, $15 \%$ for intermediate processing and the remaining $65 \%$ to be deposited at various landfill sites. Besides, the existing legislations on waste management were reviewed to improve solid waste management by privatizing it and to increase recycling awareness in the country (MHLG 2003).

This alarming situation in waste disposal management prompted the Malaysian Government to launch the $6^{\text {th }}$ Malaysia Plan (MP) for 1991-1995, with an emphasis on diversifying the sources of growth of the wastes. The $7^{\text {th }}$ Malaysia Plan (MP) for 1996-2000 also focused on the quality of life and the environment. As the population continued to grow and available lands were becoming scarce for acquiring landfill sites due to opposition by residents and community leaders, in the $8^{\text {th }}$ Malaysia Plan (MP) for 2001-2005, a National Recycling Program was re-launched with these objectives as follows:

a. Inculcate the habit of recycling among the population;

b. Reduce operational cost of solid waste management;

c. Minimize the volumes of waste disposal by landfills;

d. Reduce utilization of raw materials; and

e. Improve awareness and cooperation among stakeholders (MHLG 2003).

Under the $9^{\text {th }}$-10th Malaysia Plans and with the implementation of the Solid Waste Management Bill, the recycling and disposal of solid waste will be privatised in order to improve services, relinquish the financial burden and include the private sector. These concessionaries are responsible for collection, storage, transportation, treatment and recycling of all of the country's non-hazardous wastes (Market Watch 2011).

Taking this background information into consideration, this study attempts to understand the waste situations, waste management, waste recycling situation, recycling problem, and potentials of recyclable materials in Malaysia.

\section{WASTE MANAGEMENT SCENARIO IN MALAYSIA}

Malaysia started the privatization of waste management operation in 1994 (Budzik et al. 2002). Gradually waste collection and public space cleansing service are being taken over by Alam Flora Sdn Bhd. To smooth the process, the consortia were instructed to take over the solid waste management over an interim period. The full-flash privatization is still to be determined by the government pending legislation based on the new National Waste Bill. Until the privatization is fully implemented, most aspects of solid waste management will be continued to be in the realm of Local Government.

Although the current large-scale privatization entails a more comprehensive transfer of activities and function than the previous semi-privatization measures, the public sector cannot pass all responsibilities onto the private sector. Since the waste management privatization was initiated on national level, the Federal Government will be responsible for 
ensuring that the consortia conform to the standards, and rules and legislation as required by the Government. This is done via the Department of Local Government at the Ministry of Housing and Local Government (MHLG) while the Department of Environment (DOE) its responsibilities lie mainly in general pollution control and Environmental Impact Assessment (EIA) of waste treatment facilities (Hassan 2002). The federal government has now taken over management of solid waste with the creation of the National Solid waste Department and the bill was signed into law this 2011.

The actual operationalization of the MHLG's responsibilities lie significantly with the local authorities, who will remain central in terms of enforcing laws and regulations and ensuring that private sector meets required standard and quality (MHLG 2003). As part of the privatization process, the fees for the waste management services are now no longer the responsibility of the local authorities but must be managed by the waste management company. The particulars of this financial aspect of the waste services have not yet been addressed, but as the fee is not planned to be included in the semi-annual assessment rates imposed by the local authorities, a separate fee must be introduced. The introduction of such a fee meets some political and public opposition in Malaysia (Hassan 2002). The fees have not been settled till date between the private companies with the government as it has some political undertone because the public don't want to pay for perceive unseen service.

The interim period status of the solid waste service provision has resulted in uncertainty by both the concessionaires and the Local Authority's especially the wait for the imminent National Waste Bill and the issues of service fees are creating some implications in regards to further development and final realization of the privatization process. It can be argued that these uncertainties pertain to a reluctance to invest in new resources and equipment by various stakeholders has resulted in relative short-term planning.

\subsection{Waste collection and transportation}

Waste collection in Selangor is managed by the Alam Flora Sdn, though they employ private collection companies to deal with the actual waste collection. In the waste concession area of Alam Flora Sdn Bhd, private waste contractors are responsible for more than $50 \%$ of the total amount of waste collected. Community collection initiatives so called community self-help or "gotongroyong" activities also have a role in collection activities. Collections times vary from 2-3 times a week, and collection methods will also vary, common collection points e. g. containers where household are required to bring their waste in front of the house for easy collection. Door to door is another common collection method in Selangor especially for individual houses and link houses (Karen et al. 2003).

\subsection{Waste recycling in Malaysia}

In Malaysia, there are three types of recyclables such as Paper, plastics and bottles, but very little of the waste is recycled. In Kuala Lumpur for example, the current recycling rate is at 4. $5 \%$ of the waste generated. There is a plan to increase it to $16 \%$ by 2005 and $20 \%$ by 2020 (MHLG 2003), which is still valid till date.

A newspaper article published in The New Sunday Times, describes the Malaysia attitude towards recycling as a Not-In-My-Backyard (NIMBY) syndrome when it comes to issues of waste. People are also wary but still Malaysians only recycle less than 5\% of all the 
waste (New Sunday Times 2002). This opinion is supported by other sources that claim that the waste consciousness in Malaysia is poor, and most people don't wish to take a more personal endeavour in a matter mostly associated with dirt, filth and odours.

However true this statement may be, Malaysians have begun to recycle more as Malaysia launched first official recycling program in the peninsular Malaysia at sometimes in 1993 and was initiated by the MHLG. The stated objectives of the national recycling program was (i) to divert valuable resource in the waste stream from disposal and (ii) to help control cost of managing waste (Karen et al. 2003). The recycling program of most Local Government was envisioned as comprising of setting up of buy-back centres and the placement of drop off containers for recyclables at strategic locations such as schools, shopping malls, and so on. According to the report at the start of the national recycling program, 23 Local Government of peninsular Malaysia had volunteered to become participants of the program. But because of poor planning and lack of public participations the number of participants of the program declined to only 10 Local Government in 1998, many of the Local Government then chose not to continue with their recycling program.

The Ministry of Housing and Local Government (MHLG) re-launched the recycling programs in December 2000 to make a difference from the first failed launching of the program. In this second launching of the recycling program, participants were chosen by the MHLG, 29 Local Government of Peninsular Malaysia were chosen based on several criteria. One of these criteria was the volume of waste generated by the municipalities. MHLG provided every participant with special drop-of containers for recyclables and these containers must be placed at strategic locations of the municipalities.

To encourage public participation in this second recycling program, the MHLG engaged the services of one of the local public relation company in the city to carry out productions of pamphlets, posters and billboards, and commercial advertisement, and even recycling song to spice up the occasion. Also in addition to this, many of the major cities in Malaysia several buy-back centres established for easy deposition of recycling materials.

Another big difference in this second national program was the MHLG involved several companies that were known to be major producers of recyclable materials to participate in the recycling program. It initially involved only 23 municipalities when the program was first launched but later evolved up to 145 municipalities across the country. The main objectives are to reduce the costs of solid waste management/operation as well as to conserve resources.

Although recycling activities could be said to be on the rise, the materials recycling industry in Malaysia is demanding much larger quantities of recyclables. For example, Malaysia News Print Industries Sdn Bhd was forced to import 50\% of its materials, and Kuala Lumpur Glass Manufacturing Sdn Bhd also imported 20\% of their materials (New Sunday Times 2002). This data is still same as the material recycling rate is still 5\% till now, and raw material is not enough for these local companies.

\subsection{Waste treatment}

In Malaysia waste treatment and disposal facilities for waste in general is still lacking behind. The few incinerators that do exist do not have the capacity to deal with the exiting amount of 
waste and direct dumping are therefore the most applied method to dispose waste. No waste to energy facilities exists in Malaysia; although composting alternatives are being studied but no concrete activities have been undertaken (CAP 2001). Plans are underway to construct several new incineration plants in Malaysia; public opposition plays a large role in the approval of incineration site. One incineration is located in Southern Kuala Lumpur with a capacity of 1.500 tons/day, taking about $50 \%$ of Kuala Lumpur's daily waste generations.

In 1990 there were about 230 Landfills in Malaysia with an average of 15 hectares each. More than $80 \%$ of the landfills have an estimated remaining lifetime of two years. Almost all landfills in Malaysia are developed and operated on ad-hoc basis and the management and operation are generally poor as a result of this. About $60 \%$ are open dumps and do not have adequate facilities such as weighing bright, fence and cover materials. Furthermore, no site suitability studies have been undertaken and there is a lack of pollution control and measuring in particular for leachate and gas emissions (Karen et al. 2003).

\subsection{Waste management practices in Malaysia}

Malaysia like every other developing country is facing problem of waste management. Waste management and recycling is largely influenced by the lack of planning and implementation in accord with the waste management hierarchy of reduce, reuse and recycling (3R) (Agamuthu et al. 2009). This has resulted in a waste management system based almost on waste disposal on landfills. Solid waste disposal is therefore one of the major issues in Malaysia waste management practices today.

Many landfills are not properly managed and maintained, and few or none of the landfills have EIA or other site suitability evaluations performed. Due to this, landfills are often located too close to residential areas or other public areas. Many landfills are also located near streams and rivers, which not only cause river pollutions, but also ground water is at risk of contaminations. Uncontrolled emissions of greenhouse gasses are also problematic-especially methane. Waste are dumped in rivers, drains and streams that often not collected, and little or nothing or no waste is composting take place which means that the waste takes up spaces, and landfill life time are often much shorter than their expected time of existence. The issue of illegal dumping is also relevant in this regard (Wai 2007).

\subsection{Post waste material management and disposal}

Transportation and collections of waste are another concern in Malaysian waste management practices, especially in urban areas, e. g Kuala Lumpur, where some streets are narrow and compactor trucks are unable to pass (Mokhtar et al. 2002). The most visible part of solidwaste management is collection and transportation. After the collection of waste from their homes, offices, or industries people have no interest in where it is taken or what is done to it. Very few residents have seen disposal sites such as incinerators or landfills. Door-to-door collection is provided to all landed properties. Those living in apartments and illegal settlements have to bring their waste to the community bins. Generally the collection of waste is done three times a week on alternate days except on Sunday. In some apartments, shops, and business offices the collection of waste is done daily, except Sundays. In vegetable markets the collection is done daily including Sunday. In areas of unplanned or illegal settlements, collection is done once or twice a week. 
But on festive occasions such as Chinese New Year or the end of Ramadan (fasting) month, frequent collection service is provided. The collection and transportation system in Malaysia is fairly common. From the 1980s this activity has been privatized (Lee 2007). Since major settlements are under local authorities, collection and transportation is available to all residents except those living in isolated areas such as the hilly region. On Penang Island, the infrastructure is relatively better, and almost $95 \%$ of the residents are provided with a solid-waste collection service. There is no special service provided to collect garden waste as it is included in household waste. Sometimes it is left along the roadside or burned. Some bigger municipal authorities provide a special service once a week to collect garden waste.

For this service, the owners need to cut the waste into manageable pieces or bag the leaves to facilitate collection. On-call, chargeable service is also available in some local authorities. The local authorities are required to submit reports on the status of recycling in their areas. Unfortunately, according to the ministry, the response has been poor, and with unreliable data (New Strait Times 2001).

\section{WASTE MANAGEMENT LEGISLATIVE AND INSTITUTIONAL FRAMEWORK}

In the waste management legislations in Malaysia, it is not just only the Ministry of Housing and Local Government (MHLG) that sees to the issue of waste management. There are other related bodies of the Federal Government that are also involved in the overall planning of waste management at the conception stage together with the MHLG. These main stakeholders are the Department of Environment (DOE) and Economic Planning Unit (EPU). Though, the EPU does not have competence and responsibilities in relation to waste management, which are important to take into considerations but help finance new projects (MHLG 2003).

These departments don't work in isolations of other but together in making overall legislation on waste management for the state or regional and local authorities to implement at grass root levels. That means that the Federal, State and Local Authorities have significant roles to play in waste management stream in Malaysia. All these federal agencies are involved in waste management as decisions-makers within their areas of authorities. They are not directly involved in daily functioning and performance of waste management services, but in their role as planners and developers of sound legislative framework and control the coherence existence between local, regional/state and federal waste management plans (Karen et al. 2003). When the issue of privatizations came up, these agencies became an important strategic partner in coordinating and planning since they must be the central and coordinating body in ushering in different private waste concessionaries in Malaysia e. $\mathrm{g}$, Alam Floral Sdn Bhd. A look into the roles of these agencies who calls the shot in waste management at federal levels, region/state and local government in waste management in Malaysia will help understand the legislative framework of the Malaysian waste management system.

In Malaysia, waste management is still under the Local Government. The powers of the Local Authorities are set by several legislations including the Local Government Act 1976, the Street, Drainage and Building Act 1974 and Urban and Country Planning Act 1996. Local Authorities are however required to create their own bylaws to enforce the legislation (Karen et al. 2003). As the waste management responsibilities are under the jurisdiction of 
the Local Governments, whether under their own operations or contracted out "there is certainly no need to enact laws to regulate themselves (Local Government) and the contractors are bound by contract" (Hassan 2002).

The MHLG are responsible for the implementation of waste management and recycling rules at the Local Government level, and thus has a key role in the preparation of waste management and recycling policies, strategies and plans. MHLG processes requests for funding of projects and pass these to the Economic Planning unit (EPU) within the Prime Ministers Department. For MHLG process requirement for funding, it is also the responsibility of MHLG to provide guidelines for the waste management and recycling and to advise and assist Local Authorities on all issues relating to waste management (Karen et al. 2003).

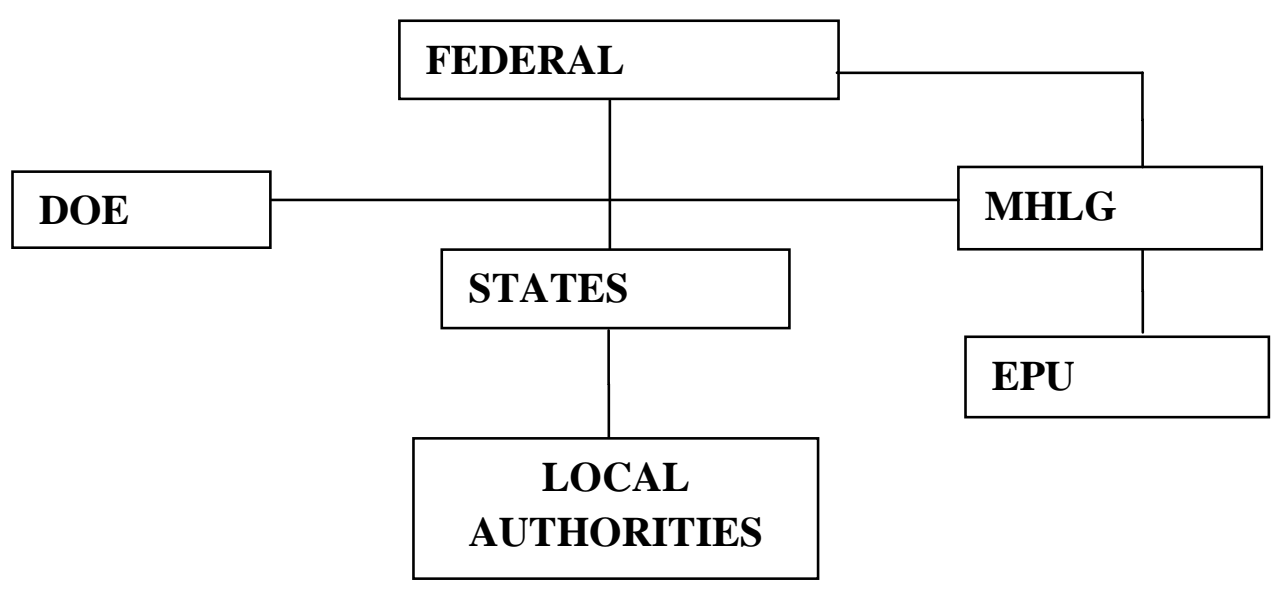

Figure 1: Stakeholders of Waste Management in Malaysia Source: MHLG (2003)

Malaysia as at 2003 has no national solid waste management act, but this has recently been approved in 2010. But before the approval the laws and regulation in the field of waste management are spread over arrange of Acts. The framework for environmental regulation in Malaysia is the Environmental Acts for waste treatment facilities (Karen et al. 2003). These issues are primarily characterized by a concern for public health and sanitation matters and not by a more holistic and integrated approach to waste management involving aspects of environmental and urban planning, social-economics, geology, etc. (Hassan 2002).

\section{i. Department of environment (DOE)}

This federal department has the principal responsibilities for preventing and controlling of pollution as well as the quality of the country's environment. All powers of this department were derived mainly from environmental Quality Acts of 1974. DOE has written guidelines for the preventions of pollutions for industries and have established national emissions effluent standards, likes the Clean Air Regulations of 1979, the Environmental Quality, (sewerage and industrial Effluent) regulations of 1979 and the Environmental Impact Assessment (prescribe premise) order of 1987.

On the issues relating to waste management in 1979 , the DOE has made it mandatory for all new municipal landfills in the country and solid waste facilities such as composting 
plant, incinerators, recycling facilities to submit an Environmental impact assessment for approval to the Director-General of DOE before executions.

In 2000, the DOE has received nine preliminary reports of EIA on sanitary landfill projects which were approved for construction, DOE roles may be viewed as broadly concern on final disposal of waste, because it's environmental and public safety implications. The departments have also prepared a guidebook called "Recommended Code of Practices for the Disposal of Solid Waste on Land" which contains basic technical information's and suggestions on site selection, construction, operation and closure of sites that were utilized for disposal of solid waste.

The DOE thus have been directed towards regulating and monitoring the hazardous waste situation of the country. The other roles that are important DOE is playing in Malaysia have been limited to review and approval of EIA reports of solid waste facilities such as landfills and incinerators. The DOE also assists local authorities through the states in providing them with officers to provide them with technical trainings.

\section{ii. Economic Planning Unit (EPU)}

EPU is not directly involved in solid waste management, but EPU in general is the central planning agency for the Federal Government of Malaysia while this agency is the main agency that prepares and reviews the country's five year development plan, it is also the initiator and coordinator of many large federal government projects.

As a federal authority responsible for privatization process of the solid waste management sector, EPU plays a significant role-especially during the continued waste sector privatization interim period. It also helps in financing new studies and projects for local authorities (MHLG 2003).

\section{iii. State Authorities}

Under the legal framework of Malaysia, the State Government is responsible to create local government. In additions, the responsibilities of most states of peninsular Malaysia states, for the local authorities include i) defining the administrative boundaries of each local authorizes, ii) appointment of the president and the President and Council members. Regarding to solid waste management and recycling, the state government through its agents, process state own properties, to be used as municipal solid waste disposal sites. In fact, the state helps to promote and coordinate activities related to waste recovery and recycling to assure people's acceptance of the program and to avoid duplications. It undertakes manpower development training programs for local authorizes who are involved in recycling programs.

\section{iv. Local Authorities}

Local authorities are the implementing agencies and have direct responsibility over solid waste collections, treatment and disposal. The fact that waste management and recycling is the responsibilities of the local authorities; it gives these local authorities stakeholders some level of autonomy in their role as decision makers. Not only do they coordinate all sorts of waste management functions-including the operations between private and public actors and planners too. 
As soon as the interim privatization is over, the role of the local government in Malaysia waste management and recycling will change. Here the local authorities are still responsible for the implementations and enforcements of matters regarding waste management and recycling. Even if they have to outsource to another organization to perform it on their behalf, such as Alam Flora, but as far as waste management has not been fully privatized, local authorities must still conduct some of the tasks that Alam Flora SdnBhd will eventually be taking over in the future. The local authorizes will still have responsibilities for regulating and evaluating the services performed by Alam Flora SdnBhd, creating awareness of government recycling programs and waste related issues. The figure 1 below shows stakeholders in Malaysian waste management legislative framework.

\subsection{New Initiative: New National Solid Waste Department}

In April 2007 the much anticipated National Solid Waste Department has been created making waste a national issue, and taking the responsibility of waste from Local Authorities' (Yahaya 2007b). To change the Act as Law, it has been postponed for the third time, and approved in 2010 with the following changes. However the bill has been signed into law in 2011.

- A standard and integrated system of waste management through promoting a more efficient operating procedure;

- Cost-efficient waste management by commissioning regional landfills within the state boundaries; and

- Private sector waste management enterprises applying for licenses will be vetted based on cost effectiveness of the projects, their environmental friendliness and technological capabilities.

Moreover, a service committee at the state level will allow the local councils to offer suggestions to the concessionaries. It will also be made compulsory for homeowners to separate wastes into dry wastes and wet wastes within two to three years on the enactment of the law, when kitchen wastes will be collected twice a week and recyclable or dry wastes will be collected once a week. This will reduce the quantity of landfill wastes into half and extend the lifespan of the sites.

In order to encourage a higher recycling rate take-back and deposit rebate schemes will be implemented, where people will be encouraged to return recyclable wastes such as plastic containers for a token sum of money, leading to a hygienic environment for the scavengers. Additionally, lorries will unload in sheds so that the scavengers can carry out their jobs before the wastes go to their destined landfills. There are also plans to utilise kitchen wastes as composts (New Sunday Times 2009).

With the creation of the National Solid Waste Department, it means a total overhaul of the old system when solid waste management was under the control of Local Council which has been the system since 1976. This means more fund are needed for the concessionaires who will not act in temporary basis. There should be no more excuse from the concessionaries to perform below expectations as their contract will become permanent, enabling them acquire more modern equipment and can engage seasonal experts in their management. Local Authorities will now play an advisory role, enabling them to concentrate in other areas, like, planning, health and revenue collection. 
But it is not yet rosy for solid waste management in Malaysia, even with the recent takeover of waste management by the Federal Government from States and district councils. A report (Sun Paper 2010) on Sungai Petani in Penang said, recently a concessionaire appointed by the federal government for the southern region reported that things has become worse. In view of this, the Local Authorities have neglected largely the departments in charge of cleansing of solid waste. Public cleansing and management should be the responsibility of Local Authorities.

Apart from small countries like Singapore and Brunei, there are very few other countries in the world where public cleansings are a Federal matter. The one Billion Ringgits allocated to the department, if it is given to the Local Authorities, there is no doubt it will improve their capacity. The Local Authorities had not been up and doing in keeping their municipalities clean. They surely need assistants from federal Government to perform well.

\section{PROSPECTS OF WASTE RECYCLING IN MALAYSIA}

There will always be wastes. The issue is how to manage it as a resource and not as a problem, so that it will not have negative impacts on people and the environment. A significant challenge facing developing countries is the search for appropriate solution for collecting, treating and disposal of waste or reuse of waste materials generated in municipal and community areas. Recycling of waste is a challenge confronting many developing countries as urban cities are in the increase of population and so is the waste generated. There is low level of recycling in many developing countries; either because of ignorance or apathy towards recycling (Wai 2007).

Recently the Selangor state government is considering a proposal to recycle and turn it into an income generating venture as most local council spend up to $30 \%$ of their local budget on rubbish collection and some up to 60\% (Daily Metro 2008). The recent creation of a National Solid Waste Department is stepping in the right direction as this will relieve the Local of the financial burden of managing waste (Yahaya 2007a).

The traditional method that the country has been using is to use the landfills for waste disposal of waste, and overtime buries them with soil. But Landfills require huge plots of land and usually fill up very quickly. Some big landfills have been closed down due to reaching their capacity, as well as the suitability of the locations which use to be far away from residential areas, but are no more due to population and township growth. Some examples are the Kelana Jaya dumpsite (now filled with condos, a stadium and commercial development). Subang Airport road used to stink badly whenever you use the road to airport, but is now a residential area with condos and houses. Sri Kembangaan/ Air Hitan were also closed down and also Selaying Landfills (Wai 2007).

The alternatives of landfills like incinerators, particularly of gigantic types but still unknown status Broga incinerator in Semenyih which courted controversy due to questions about its location in a catchment area as well as the Japanese contractor which has a questionable project back in his home country. Nobody likes to have a waste processing plant behind his or her backyard. The incinerator was first proposed to be in Puchong but was relocated due to residence and political pressures. Something has to be done to cope with its 
ultimate disposal. The government is to tackle the problem even though the idea of smaller, more efficient and manageable incinerator would be idea than the biggest incinerator.

People living in the peninsula especially Selangor should be encouraged to cultivate the habit of reducing waste by recycling as in developed countries where it has become of thing habitually even from younger age (Wai 2007). The high economic growth in recent years in Selangor requires a sustainable means of managing waste. The recently created National Waste Department has been a way forward to that effect.

Selangor government could borrow a leaf from Europe where recycling has become a habit of life as in the case of the Cliff Borough Council in East London. The Cliff Borough Council in East London, in 2001-2002, recycling rate was just 9. 7\% but it jumped to $48 \%$ in 2003-2004, and reached to 50\% by December 2004, suggesting that CBC may become UK's biggest performing local authority. The study of RCR suggested that a well-designed communication campaign and an effective marketing strategy is the key to achieving success in recycling programs.

There is a proposal by the government for some years to enforce compulsory garbage separation in Selangor. It is not an easy thing to do even though it could have succeeded in some countries like Taiwan, as their culture values and geographical location differs from that of Malaysia. The fact that policy worked in Taiwan does not mean it workshere; therefore Malaysia should find policy that should be wholly accepted by her citizenry (Wai 2007).

The state has now intensified its effort through integrated waste management system of reducing waste through sustainable waste management of $3 \mathrm{R}$ and final disposal. Awareness of this program is being carried out through campaigns, mass media and lectures. At the same time the State Government is facilitating through the Ministry of Housing and Local Government to provide facilities such as waste bins and collection centres households (MHLG 2006).

Recently residents in Selangor are required to separate their waste into organic and inorganic waste for easy collections and recycling by Alam Flora Sdn Bhd. Although the new rule attracts no penalty for failing to do so, household waste could be refused to be collected by Alam Flora for failing to separate their waste accordingly (Bavani 2009). On the other hand Shopping Malls in the state are now required not to give plastic bags on every last Saturday of the month to shoppers. Shoppers who insist on collecting bags are required to pay 20 cents for each plastic bag collected and the money will be channelled to the charity homes in Selangor chosen by the state. Below are Figures 2 and 3 showing the current recycling rate and recycling target for Selangor in the year 2020.

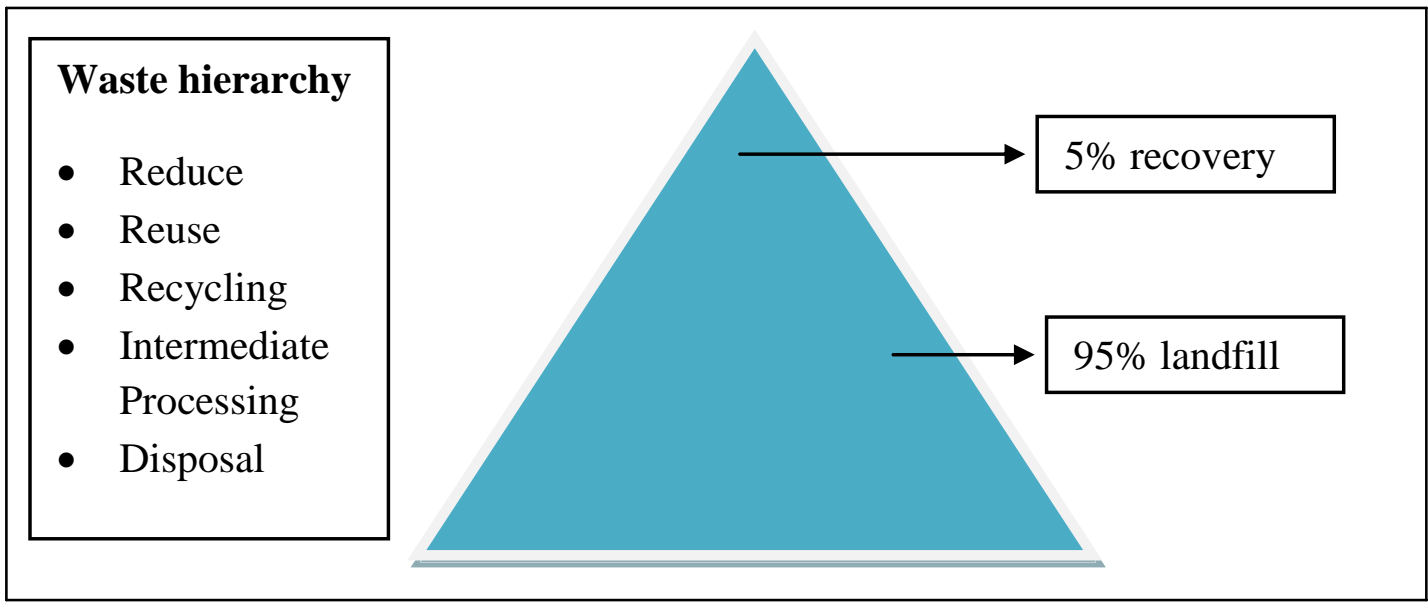


Figure 2: The current waste management system in Selangor Source: Ministry of Housing and Local Government (2003)

From the figure 2, it shows that the current waste recycling and recovery is only 5\% of the total waste generated in the state while the rest $95 \%$ is sent to landfill. Land has been the traditional method system of waste disposal in Selangor.

This trend has been going on for ages in Malaysia, as there are abundant lands to deposit waste. But with the increase in population and high growth of economy in Malaysia in the last decade, there are calls for a more sustainable system to dispose waste without much environmental effect as land is running out and becoming expensive to build landfills.

The use of "sustainable landfills" by some authorities could have been the reason behind the recent construction of the biggest landfill in Malaysia, the Bukit Tagar sanitary landfill in Ulu Selangor $50 \mathrm{~km}$ north from Kuala Lumpur in Selangor which started operation in 2005 occupying a capacity of 1,700 acres of land with 120 metric tons of air space.

Malaysia has to develop sustainable methods of waste management, but at the same time accept that achieving this goal is long way off. But for the moment recycling is the only sustainable method to reduce waste.

Figure 3 shows the strategic recycling target of Selangor Government with integrated waste management of reduce, reuse, recycling, intermediate processing and final disposal to increase waste recycling rate and recovery in the 8MP till 2020. This target is feasible if appropriate policies and technology are in place.

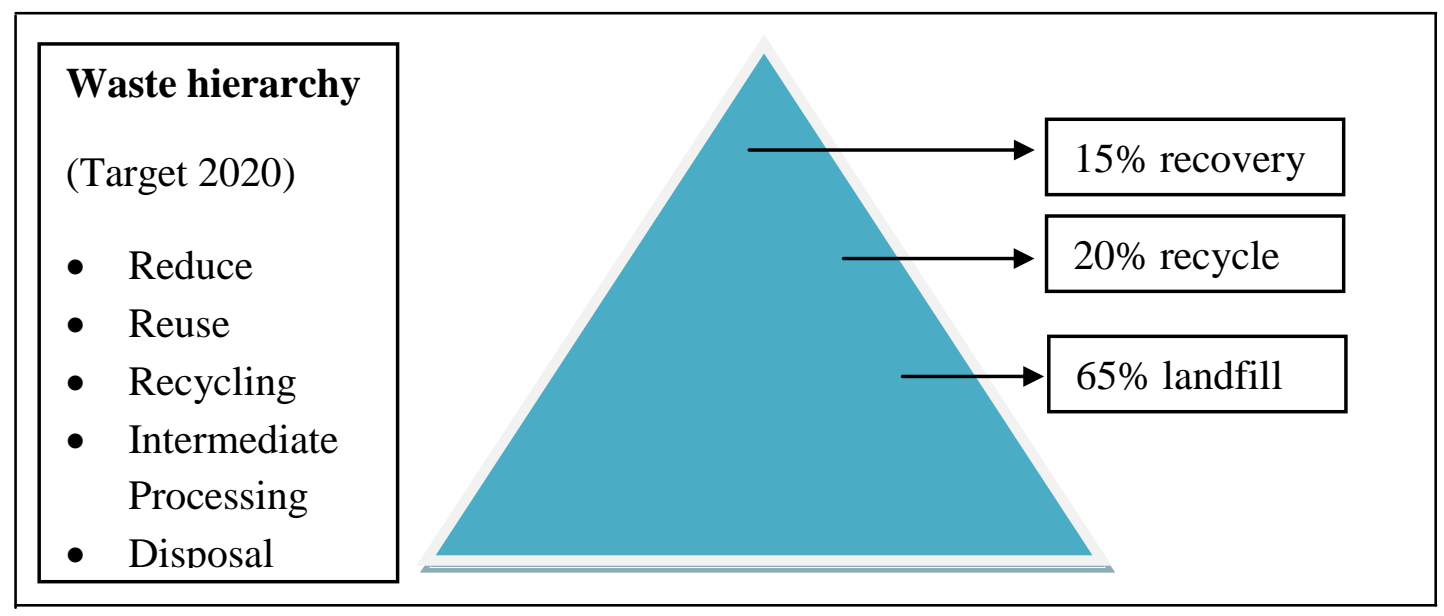

Figure 3: Waste recycling targets for Selangor in the 8MP for 2020

Source: Ministry of Housing and Local Government (2003) 
There is still insufficient emphasis being played by local authorities and others on the whole of question of re-use. We are all familiar with these sticky labels that enable us to reuse old envelopes, but have many of operators of business or local authorities that can reuse our items. That notwithstanding, the Selangor Government is encouraging, households; offices to either give out their old materials to those in need when refurnishing their offices or homes than throwing it into the waste stream. Reusable bags are sold at some shopping malls that are also biodegradable. People are encouraged to buy household items that are refillable, like hair cream, beverages and some soft drinks with plastic bottles etc. so as to reduce waste at households' level.

Recycling has become a known issue since the launching of the first national recycling program in 1993 and the launched of it in December 2000 in Malaysia. The Selangor Government has in many ways disseminating this massage to her citizens, that recycling is a sustainable means of managing waste so as to attain the state target of $20 \%$ diversion of waste sent to landfills in 2020.

This is being made possible by provisions of waste bins at strategic places in the state and privatizing waste management. Households are encouraged to separate their waste into wet and dry waste for easy collections and recycling, though not compulsory. But for Malaysia to achieve her target of $20 \%$ recycling rate in 2020 more proactive measures has to be taken by making waste separation compulsory at household levels and with the imposition of fines for failing to separate their waste.

Other waste hierarchy plans of Selangor to be achieved in 2020 is the establishing of an intermediate processing facility in state where recyclable materials will be sorted by types, compacted, baled and sold to many manufacturing companies in the countries that use secondary raw materials for productions and also for export. Intermediate processing facilities will process and market newspapers, mixed paper, cardboard, plastic, tin can, glass and aluminium received from various parts of the state of the country and for export as well.

\section{CONCLUSION AND RECOMMENDATIONS}

Disposing of wastes in a landfill is one of the most traditional methods of disposal, and it has been a common practice in most countries, even in Selangor, Malaysia, as has been mentioned earlier. However, a properly designed and well managed landfill - which is a relatively inexpensive method of depositing waste materials - can improve the hygienic wellbeing of people significantly. Due to opposition in Selangor for establishing new landfills and the issue of NIMB, landfills are located far away from residential areas in the state which increases cost of disposal for the local councils. The state has a target of only $65 \%$ of wastes to be deposited into landfills in 8MP in 2020 from its present rate of $95 \%$. This is a step in a right direction, which has reduced the cost for waste management in the state (MHLG 2003).

The SWM Act 2007 introduced by the Government which has now become legal emphasis compulsory system of waste hierarchic of the 3Rs: reduce, reuse, and recycle. This is an important campaign included in the Act. The implementation and enforcement of the 3Rs are also listed in under the act. Solid waste generators are required to reduce the generation of solid waste; to use environmentally friendly materials; to limit the generation, import, use, discharge, and disposal of specified products; to implement coding and labelling on products to promote recycling; and to utilize any method to reduce the adverse impacts of 
municipal solid waste on the environment, i. e. to reduce, reuse, and recycle of MSW (Lee 2007).

Although waste minimization is emphasized in the Act, the techniques to reduce waste generation are not specified and the options are too generalized (Agamuthu et al. 2009). Failure to comply with the law will make the offender liable to a fine of up to RM10,000 (US\$2632) or up to 6 months imprisonment, or both. The government of Malaysia has plans to manage household waste efficiently to ensure a clean, fresh, and sustainable environment. For all these initiatives yield the desirable results, it should be followed by monitoring to insure if the goals set up are being achieved.

Unlike the people of the western countries and Japan, Malaysians have not fully embraced the recycling activities. Those who do it are very small in number and do it for economic reason only. This is evident as only $5 \%$ of the wastes are recycled in Kuala Lumpur - which is lower than the rate outside of Kuala Lumpur - and the rest are sent to the landfills.

In Malaysia there are abound potentials for recyclable materials, as much as $80 \%$ of the wastes generated could be recycled and this could be utilized to reduce overall waste generation. But inadequate policy and lack of separation at source for waste materials have been militating factors to increase recycling in Malaysia. Recycling activities can gradually be accepted if the policy and technology are friendly as it can help reduce disposal cost for local authorities and accompany economic benefits.

Many developed countries have greatly accepted the policy of "pay-for what -you throw-away "program. Unit pricing has been an effective means to reduce waste through increasing cost for households. It is generally believed by the developed world that when you know that if you generate much waste you will pay for it. That intrinsic believe of high cost of waste disposal by households will surely compel them to be careful how to generate waste in their households and to recycle more of their waste. This policy have highly motivated households to cultivate recycling habit more though difficult to implement in developing countries like here, but could gradually be implemented with time and the people will be used to the system.

Policy implementation whereby communities are involved in policy formation is very important for effective recycling program as it helps create sense of belonging and ensure the policies effectiveness in their locality. In addition recycling should be made mandatory rather optional and as well as source separation of waste at households. There is need for recycling convenience as it suits the community.

Thus, there is a need for aggressive campaigns based on the concept of 3R. Policy implementation should be vigorously implemented and not based on theory which has always been the system before. Failure of sound implementation has always been the bane in the past for most recycling programs. If recycling is adopted it will help generate employment, reduce greenhouse gas and energy consumption, conserve natural resources, and reduce the cost of disposal for the local councils. Recycling has the potentials to reduce overall waste generation and at the same time an entrée point to participation in environmental awareness.

\section{REFERENCES}


Agamuthu, P. , Hamid, F. S. and Khidzir, K. 2009. Evolution of solid waste management in Malaysia: impacts and implications of the solid waste Bill 2007, Journal of Mater Cycles Waste Management, 11: 96-103.

Bavani, M. 2009. Separate your waste from June 1, The Star, April 29. (online) <http://thestar.com.my/metro/story. asp?file $=/ 2009 / 4 / 29 /$ central $/ 3782260 \&$ sec $=$ central $>$

Budzik, M. Jonathan,M. , Luciano, A. and Juliana, P. 2002. Waste Management Overseas The Malaysian experience, Dec. (online)<http://www.ecowaste. com/swanabc/papers/budz01.htm> (accessed on Dec, 2002)

Child, R. 2004. Resource Conservation and Recycling, Cliff Borough Council Recycling Progress Report in Eastern London.pp.1-25.

Connett, P. 2010. Incineration: A poor solution for the $21^{\text {st }}$ century, (online) <http://www. slideshare. net/FrankieDolan/incineration-a-poor-solution-for-the-21st-century-by-drpaul-connett> (accessed on 10 October 2012)

Consumers Association of Penang (CAP). 2001.The proposed thermal waste treatment Plant for waste management in $\mathrm{Kg}$ Bohol, Mukin Sungai Besi, Kuala Lumpur.(online)<http://www.surfforever.com/sam/pressurelease/kgbohol. html $>$ (accessed on 10 October 2012)

Daily Metro. 2008.Money in recycling, 7 May.

Lee, G. B. 2007. National Reports: Malaysia. In Solid Waste Management: Issues and Challenges in Asia,Report of the APO Survey on Solid-Waste Management 2004-05, Environmental Management Centre, Mumbai, India. (online) <http://www.apotokyo.org/00e-books/IS-22_SolidWasteMgt.htm>(accessed on 10 October 2012)

Hassan, M. 2002. Environmental Management in Malaysia: E. I. A process in Malaysia. Ministry of Resources and Environment.

Karen, A. K. , Nash, A. , May, L. C. and Knudsen, 2003. Household Hazardous Waste Management and Stakeholder's involvement in Kuala Lumpur. Department of Environment, Technology and Social Studies, University of Roskilde, Denmark.(online) <http://rudar.ruc.dk/bitstream/1800/206/1/Household\%20_Hazardous\%20_Waste.pdf $>$ (accessed on 10 October 2012)

Wai, Ko-chi.2007.Reduce, Reuse and Recycle. (online) <http://waikc.blogspot.com/2007/06/reduce-reuse-recycle.html> (accessed on 10 October 2012)

Ministry of Housing and Local Government (MHLG) 2003.Overview of solid waste management in Malaysia, Kuala Lumpur, Local Government Department.

Ministry of Housing and Local Government (MHLG) 2006. Waste management and the Challenges, Kuala Lumpur, Local Government Department.

Mokhtar, M. B., Peterson, P. J. ,andFariz, A. 2002. Approaches towards sustainable environmental and national resources management for ASEAN regions.LESTARI,UKM, Bangi, Selangor, Malaysia.

Market Watch 2011. The $9^{\text {th }}-10^{\text {th }}$ Malaysian planThe Environmental Sector in Malaysia

New Strait Times.2001.Waste management's and recycling problems: data issues. 16 April.

New Sunday Times.2002.National New Solid Waste Department, October.

New Sunday Times.2009.Not-In-My-Back-Yard Syndrome (NIBM). 18 January.

Perunding.2001. Solid Waste Management in Malaysia: Overview and Information Paper, Danish Cooperation in Environment and Development, March. 
Polprasert, C. 1998. Organic waste recycling. Asian Institute of Technology,

Thailand.(online) <http://llrc.mcast.edu.

mt/digitalversion/Table_of_Contents_132294.pdf $>$ (accessed on 10 October 2012)

Sun Paper. 2010. Sungai Petani in Penang.13 April.

Yahaya, N. 2007a.Solid waste management, Conference on climate change preparedness. National Solid Waste Department. Kuala Lumpur.11 September.

Yahaya, N. 2007b. The New National Solid Waste Department. The New Sunday Time, 1 January.

Yassin, M. 2006. Speech given in the Waste Management Conference, Ministry of Local Government and Housing, Kuala Lumpur, 16 May. 